\title{
Influence of Treated Wastewater on the Percentage of Protein Content during Fodder Intercropping
}

\author{
Orwa Houshia $\left(\mathbb{D},{ }^{1}\right.$ Fuad Al-Rimawi $\mathbb{D D}^{2},{ }^{2}$ Oday Zaid, ${ }^{3}$ Motasem Zaid, ${ }^{3}$ Jaber Imoor, ${ }^{3}$ \\ Rami Casey, ${ }^{3}$ and Harbi Daraghmeh ${ }^{1}$ \\ ${ }^{1}$ Department of Chemistry, Arab American University, Jenin, State of Palestine \\ ${ }^{2}$ Chemistry Department, Faculty of Science and Technology, Al-Quds University, P.O. Box 20002, Jerusalem, State of Palestine \\ ${ }^{3}$ National Agricultural Research Centre, Ministry of Agriculture (NARC), Jenin, State of Palestine \\ Correspondence should be addressed to Orwa Houshia; orwa.houshia@aauj.edu
}

Received 3 January 2022; Revised 23 January 2022; Accepted 10 February 2022; Published 2 March 2022

Academic Editor: Yang Li

Copyright ( $(2022$ Orwa Houshia et al. This is an open access article distributed under the Creative Commons Attribution License, which permits unrestricted use, distribution, and reproduction in any medium, provided the original work is properly cited.

This study aims to explore the potential use of treated wastewater in irrigating fodder crops and its effects on protein contents. A comparison of the protein contents in intercropped fodder plants irrigated with fresh water, and rainfall water, against those irrigated with treated grey water was performed under Palestinian climate conditions. Field experiments with different intercropping mixing ratios were carried out in 2017-2019 at the National Agricultural Research Centre in Palestine (NARC). Measurements of the nutritional value of each mixture specifically the protein contents were carried out to get the optimal and best conditions for preparing animal feed crops with three different water sources used. For alfalfa with vetch, the best result for protein percentages was (on average) obtained from the rain-fed experiment (17.1\% protein) followed by the freshwater experiment (12.9\% protein) and then by the treated grey-water experiment (12.6\% protein). It appears that the best result for alfalfa with barley for protein percentages was (on average) obtained from the treated grey-water experiment (13.0\% protein) followed by the freshwater experiment (11.1\% protein) and then by the rain-fed experiment (10.5\% protein). Statistical analysis of the data showed that percent protein for each specific mixing ratio resulted in significant differences in the protein $\%$ for the those irrigated with fresh water compared with the other types of water. The highest protein \% was found to be for that irrigated with fresh water (31.9 for $10 / 90$ alfalfa/barley ratio) followed by that irrigated with treated grey water ( 28.4 for $20 / 80$ alfalfa/barley ratio) and then for the $30 / 70$ ratio irrigated with treated wastewater $(22.5 \%)$, and then for the 100/0 ratio of alfalfa/barley irrigated with rainwater (19.0). Overall, results of this study showed that cereal-legume intercropping irrigated with treated grey water can be used as a suitable management strategy for producing high-quality and high-quantity forage. Furthermore, the use of treated water can reduce the already strained demand on fresh water due to increase in population among other factors.

\section{Introduction}

Intercropping is widely used by smallholder farmers in developing countries and attracting attention in the context of ecological intensification of agriculture in developed countries [1]. Intercropping becomes particularly important in areas with limited rainfall or semiarid climates [2]. Due to low rain fall and dry areas in certain parts of Palestine [3], diminishing supply of fresh water, and the recognition of using treated water in cropping animal feed crops with significant nutritional values, intercropping was performed by growing of two or more crops simultaneously on the same field to optimize parameters of irrigation and maximize benefits of products.

Integrated intercropping of legumes is an option, therefore aiming at optimizing the agronomic efficiency of applied inputs [24]. Legume integration is an important component of agricultural and animal feed systems $[4,5]$. Legume-cereal intercropping, especially corn-beans intercropping, is common throughout many parts of the world [6]. In drier areas, common beans are often replaced by cowpea or groundnut. Farmers commonly intercrop to 


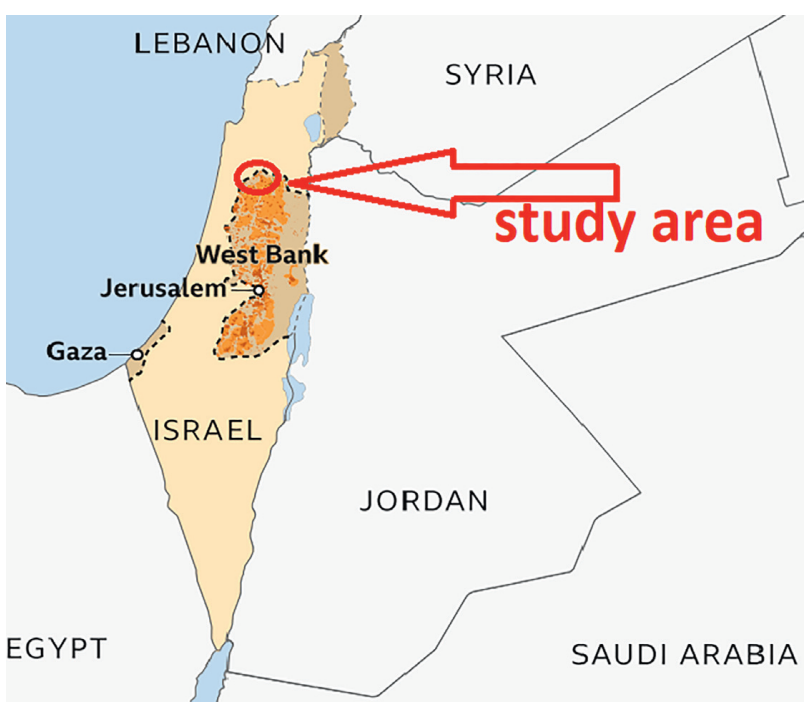

FIgURE 1: Location of the study area.

secure food production by averting risk and to maximize utilization of land and labor [7]. When crops are complimentary in terms of growth pattern, above ground canopy, rooting system, and their water and nutrient demand, intercropping effectively enables a more efficient utilization of available resources (sunlight, moisture, and soil nutrients) and can result in relatively higher yields than when crops are grown separately, as pure stands [8]. Other benefits of intercropping are related to the better soil cover, which has advantages for weed control and leads to reduced erosion and nutrient leaching [9-12]. In addition, regional irrigation with treated grey-water olive orchards and vegetable crops did not show any negative effect on the chemical properties of the fruits and leaves [23].

Because legumes can rely on atmospheric nitrogen $(\mathrm{N})$, they are less likely to compete for $\mathrm{N}$ with the cereal. The presence of a cereal, exploiting the soil mineral $\mathrm{N}$, may even stimulate legumes to fix $\mathrm{N}[13,14]$. Fodders are vital in the world's food resources as plant materials containing high amounts of structured carbohydrates [15-18]. Legumes are a good source of protein and can be used to compensate cereal protein shortage. Thus, growing of crop mixtures with legumes, which is referred to intercropping, can boost the forage protein content of diets [19-22].

Little information is available on the effect of irrigating with treated wastewater in Palestine, especially when dealing with intercropped fodder. This activity come in line with Livestock-Based Livelihood-institutional Component (LBLi); this is because the FAO works to strengthening the capabilities of and links with applied research to enhance the adoption of innovative approaches in addressing problems and opportunities in the livestock sector and how to use treated wastewater (TWW) for silage crops: quality and safety control in TWW usage, introduction of new fodder crop varieties suitable for TWW irrigation, and growing various barley and vetch species on fresh water, treated grey water, and rainwater; then, use these fodder crops in certain ratios and study the nutritional value of each mix; and then,
TABLE 1: Alfalfa/barley and vetch/barley plot ratios.

\begin{tabular}{lcc}
\hline Plots & Alfalfa/barley & Vetch/barley \\
\hline 1 & $100 / 0$ & $100 / 0$ \\
2 & $90 / 10$ & $90 / 10$ \\
3 & $80 / 20$ & $80 / 20$ \\
4 & $70 / 30$ & $70 / 30$ \\
5 & $60 / 40$ & $60 / 40$ \\
6 & $50 / 50$ & $50 / 50$ \\
7 & $40 / 60$ & $40 / 60$ \\
8 & $30 / 70$ & $30 / 70$ \\
9 & $20 / 80$ & $20 / 80$ \\
10 & $10 / 90$ & $10 / 90$ \\
11 & $0 / 100$ & $0 / 100$ \\
\hline
\end{tabular}

decide on the optimal and best conditions for preparing animal feed crops regardless of the water source used, inclusively to use treated water as alternative water supply due to scarcity of water in Palestine.

\section{Materials and Methods}

2.1. Location. Intercrops of alfalfa with barley and vetch with barley were carried out in the Northern West Bank of Palestine within the Jenin Governorate, as shown in Figure 1. The geographical area is located at latitude N32.40, longitude E 35.28, and elevation at $312 \mathrm{~m}$ above sea level (m a.s.l.). The rain-fed intercrops receive rainfall of an average of $300 \mathrm{~mm} /$ year, which were not fertilized or irrigated throughout growth. The average temperature of the year in the region was $20.3^{\circ} \mathrm{C}$ (low of $14^{\circ} \mathrm{C}$ night time and $27^{\circ} \mathrm{C}$ during daytime), and the average temperature from September to November is about $23.5^{\circ} \mathrm{C}$ (low of $18^{\circ} \mathrm{C}$ night time and high of $29^{\circ} \mathrm{C}$ daytime).

The research team implemented the project by growing various fodder crops from seeds irrigated with rain-fed water, fresh water, and treated grey water. The following crops were intercropped in accordance with Table 1 mixing ratios: barely with vetch and barely with alfalfa. Planting of the crops was done in two areas: outdoor and indoor (inside a greenhouse). For rain-fed, the barley/vetch intercropping and the barely/alfalfa intercropping were performed outdoor because both of these crops are winter crops and are not influenced negatively by the cold weather.

The experiments were carried out in three locations within the NARC facility during the 2017-2019, on terrarossa brown rendzinas and pale rendzinas soil, which is the type of soil that typically found in northern Palestine. This area of Palestine is dominated by agricultural work. For indoor experiments, barley and alfalfa intercrops were grown inside greenhouse, in which irrigation was performed using fresh water and in another plot using treated wastewater. Another batch of same intercropping was achieved outside, which was dependent upon the rain-fed irrigation method. The same was done to the barley and vetch intercropping fields. Sampling was done in triplicate.

The crops were harvested at physiological maturity. The plots were harvested manually and separated in three fractions, i.e., grain legume, barley, and weeds. The plant 
samples were dried to constant weight, and total dry matter (DM) production for each plot was determined separately for grain legumes, barley, and weeds After threshing, the grain DM yields were determined.

2.2. Analysis of Samples in the Kjeldahl Apparatus. The analysis essentially involves three steps. First, digestion of 10 grams of each sample that involves oxidative decomposition using concentrated, boiling sulfuric acid for 3 to 5 hours. The bound nitrogen is dissolved out of its bond matrix without any losses and is completely converted into inorganic ammonia nitrogen $\left(\mathrm{NH}_{4}{ }^{+}-\mathrm{N}\right)$. At the end of the digestion reaction, all the sample's nitrogen should be present as ammonia nitrogen as represented in

$$
\begin{aligned}
(\mathrm{CHNO})(\mathrm{s})+\mathrm{H}_{2} \mathrm{SO}_{4}(\mathrm{l}) \longrightarrow \mathrm{CO}_{2}(\mathrm{~g})+\mathrm{SO}_{2}(\mathrm{~g})+\mathrm{H}_{2} \mathrm{O}(\mathrm{g}) \\
+\left(\mathrm{NH}_{4}\right) 2 \mathrm{SO}_{4}(\mathrm{aq})+\mathrm{H}_{2} \mathrm{SO}_{4}(\mathrm{l})
\end{aligned}
$$

Second, the digested solution is distilled by adding concentrated base (33\% $\mathrm{NaOH}$ solution) and the ammonia is then released and distilled from this solution in accordance with the following equation:

$$
\begin{aligned}
\left(\mathrm{NH}_{4}\right) 2 \mathrm{SO}_{4(\mathrm{aq})}+2 \mathrm{NaOH}_{(\mathrm{aq})} \longrightarrow & \mathrm{Na}_{2} \mathrm{SO}_{4(\mathrm{aq})}+2 \mathrm{NH}_{3}(\mathrm{~g}) \\
+ & 2 \mathrm{H}_{2} \mathrm{O}(\mathrm{l})
\end{aligned}
$$

Finally, in the third step, applied water steam extracts the volatile component ammonia from the green-colored digestion solution and transports the ammonia through the distribution head and coiled-tube condenser into the collection solution with boric acid, which turns into pink color. The ammonia and boric acid react stoichiometrically to form ammonium borate, which prevents the ammonia from escaping. At the end, the residual boric acid is titrated with base, which provides quantitative conclusions about the nitrogen content in the original sample. The following equation shows collecting the ammonia in boric acid:

$\mathrm{NH}_{3}(\mathrm{~g})+\mathrm{B}(\mathrm{OH})_{4(\mathrm{aq})}^{-}+\mathrm{H}^{+} \longrightarrow \mathrm{NH}_{4(\mathrm{aq})}^{+}+\mathrm{B}(\mathrm{OH})_{4(\mathrm{aq})}^{-}$

2.3. Calculating the Nitrogen Content. The consumption of titration solution $(\mathrm{H}+)$ during titration of the excess boric acid can be used to simply calculate the percentage nitrogen content in the initial sample. The following formula applies here:

$$
\% \mathrm{~N}=\frac{(c e q *(\mathrm{~V}-\mathrm{VBL}) * M * 100 \%)}{\mathrm{E}},
$$

where $c_{\mathbf{e q}}$ is the equivalent concentration of the titration solution $(\mathrm{mol} / \mathrm{l}), \mathbf{V}$ is the consumption of titration solution sample [1], $\mathbf{V}_{\mathbf{B L}}$ is the consumption of titration solution at blank point (l), $\mathbf{M}$ is the molar mass of nitrogen $(\mathrm{g} / \mathrm{mol})$, and $\mathbf{E}$ is the weight of the sample $(\mathrm{g})$.
TABle 2: Percent protein for alfalfa/barley-intercropped fields.

\begin{tabular}{lccc}
\hline & \multicolumn{3}{c}{ Alfalfa/barley } \\
Ratio & Fresh water & Rainwater & Wastewater \\
\hline $0 / 100$ & $5.2 \pm 0.12^{\mathrm{Gb}}$ & $8.6 \pm 0.26^{\mathrm{Fa}}$ & $8.0 \pm 0.36^{\mathrm{Ha}}$ \\
$10 / 90$ & $32.0 \pm 0.23^{\mathrm{Aa}}$ & $8.1 \pm 0.22^{\mathrm{Fb}}$ & $7.3 \pm 0.27^{\mathrm{Ic}}$ \\
$20 / 80$ & $5.8 \pm 0.27^{\mathrm{Gc}}$ & $10.7 \pm 0.35^{\mathrm{Db}}$ & $28.4 \pm 0.15^{\mathrm{Aa}}$ \\
$30 / 70$ & $1.9 \pm 0.11^{\mathrm{Hc}}$ & $8.0 \pm 0.26^{\mathrm{Gb}}$ & $22.6 \pm 0.24^{\mathrm{Ba}}$ \\
$40 / 60$ & $24.0 \pm 0.35^{\mathrm{Ba}}$ & $14.3 \pm 0.36^{\mathrm{Bb}}$ & $11.4 \pm 0.25^{\mathrm{Fc}}$ \\
$50 / 50$ & $9.4 \pm 0.25^{\mathrm{Db}}$ & $9.7 \pm 0.14^{\mathrm{Eb}}$ & $14.5 \pm 0.32^{\mathrm{Da}}$ \\
$60 / 40$ & $6.3 \pm 0.33^{\mathrm{Fc}}$ & $10.6 \pm 0.24^{\mathrm{Db}}$ & $12.8 \pm 0.23^{\mathrm{Ea}}$ \\
$70 / 30$ & $8.6 \pm 0.25^{\mathrm{Eb}}$ & $8.1 \pm 0.26^{\mathrm{Fb}}$ & $10.0 \pm 0.41^{\mathrm{Ga}}$ \\
$80 / 20$ & $13.4 \pm 0.22^{\mathrm{Ca}}$ & $4.7 \pm 0.33^{\mathrm{Hc}}$ & $7.3 \pm 0.25^{\mathrm{Ib}}$ \\
$90 / 10$ & $9.2 \pm 0.31^{\mathrm{Dc}}$ & $13.3 \pm 0.11^{\mathrm{Cb}}$ & $15.3 \pm 0.25^{\mathrm{Ca}}$ \\
$100 / 0$ & $6.7 \pm 0.21^{\mathrm{Fb}}$ & $19.0 \pm 0.25^{\mathrm{Aa}}$ & $4.9 \pm 0.31^{\mathrm{Jc}}$ \\
\hline
\end{tabular}

2.3.1. Statistical Analysis. Three samples of each treatment were independently analyzed, and all of the determinations were carried out in triplicate. All statistical analyses were carried out using SAS (SAS Institute Inc., Cary, USA, Release $8.02,2001)$. Comparisons of means were carried out using the GLM procedure, treating main factors separately using one-way analysis of variance (ANOVA). Differences were considered significant if $P$ values were lower than 0.05 .

\section{Results and Discussion}

The protein percentages from the intercropping were determined by measuring the total nitrogen content from 3 to $15 \mathrm{mg}$ subsamples of finely ground material using the Kjeldahl apparatus. The theory is based on determination of the total nitrogen in a sample using the Kjeldahl. This instrument is one of the most accurate and widely used methods for determining nitrogen in substance such as milk, cereal, and flour. The solid is first digested in boiling sulfuric acid, which converts nitrogen to ammonium ion and oxidizes to other elements as in

$$
\text { Organic } \mathrm{C}, \mathrm{H}, \mathrm{N} \longrightarrow \mathrm{NH}_{4}^{+}+\mathrm{CO}_{2}+\mathrm{H}_{2} \mathrm{O}
$$

Mercury, copper, and selenium compounds catalyze the digestion process. To speed up the rate of reaction, the boiling point of the concentrated sulfuric acid is raised by adding $\mathrm{K}_{2} \mathrm{SO}_{4}$. After digestion is complete, the solution containing $\mathrm{NH}_{4}{ }^{+}$is made basic, and the liberated $\mathrm{NH}_{3}$ is distilled into a receiver containing known amount of $\mathrm{HCl}$. Excess, unreacted $\mathrm{HCl}$ is then titrated with standard $\mathrm{NaOH}$ to determine how much $\mathrm{HCl}$ was consumed by $\mathrm{NH}_{3}$, as shown in equations (6)-(8). And equation (8) shows treatment of the unreacted acid neutralized with base:

neutralization of $\mathrm{NH}_{4}^{+}: \mathrm{NH}_{4}^{+}+\mathrm{OH}^{-} \longrightarrow \mathrm{NH}_{3}+\mathrm{H}_{2} \mathrm{O}$,

distillation of $\mathrm{NH}_{3}$ into standardized $\mathrm{HCl}: \mathrm{NH}_{3}+\mathrm{H}^{+} \longrightarrow \mathrm{NH}_{4}^{+}$

titration of unreacted $\mathrm{HCl}$ with $\mathrm{NaOH}: \mathrm{H}^{+}+\mathrm{OH}^{-} \longrightarrow \mathrm{H}_{2} \mathrm{O}$ 
Table 3: Percent protein from vetch-barley fields.

\begin{tabular}{lccc}
\hline & \multicolumn{3}{c}{ Vetch/barley } \\
Ratio & Fresh water & Rainwater & Wastewater \\
\hline $0 / 100$ & $5.0 \pm 0.12^{\mathrm{Hc}}$ & $15.2 \pm 0.25^{\mathrm{Da}}$ & $10.6 \pm 0.21^{\mathrm{Fb}}$ \\
$10 / 90$ & $13.8 \pm 0.25^{\mathrm{Dc}}$ & $18.9 \pm 0.32^{\mathrm{Cb}}$ & $22.5 \pm 0.25^{\mathrm{Aa}}$ \\
$20 / 80$ & $13.6 \pm 0.31^{\mathrm{Db}}$ & $11.4 \pm 0.11^{\mathrm{Gc}}$ & $16.9 \pm 0.24^{\mathrm{Ba}}$ \\
$30 / 70$ & $19.3 \pm 0.22^{\mathrm{Cb}}$ & $23.6 \pm 0.26^{\mathrm{Aa}}$ & $17.3 \pm 0.22^{\mathrm{Bc}}$ \\
$40 / 60$ & $9.1 \pm 0.12^{\mathrm{Ec}}$ & $10.1 \pm 0.27^{\mathrm{Hb}}$ & $15.0 \pm 0.36^{\mathrm{Da}}$ \\
$50 / 50$ & $8.0 \pm 0.13^{\mathrm{Fb}}$ & $14.3 \pm 0.31^{\mathrm{Ea}}$ & $14.4 \pm 0.28^{\mathrm{Da}}$ \\
$60 / 40$ & $6.0 \pm 0.11^{\mathrm{Gc}}$ & $23.2 \pm 0.25^{\mathrm{Aa}}$ & $6.7 \pm 0.11^{\mathrm{Hb}}$ \\
$70 / 30$ & $1.6 \pm 0.12^{\mathrm{Id}}$ & $20.3 \pm 0.22^{\mathrm{Ba}}$ & $11.7 \pm 0.13^{\mathrm{Eb}}$ \\
$80 / 20$ & $24.4 \pm 0.25^{\mathrm{Ba}}$ & $12.2 \pm 0.15^{\mathrm{Fb}}$ & $7.8 \pm 0.23^{\mathrm{Gc}}$ \\
$90 / 10$ & $35.1 \pm 0.32^{\mathrm{Aa}}$ & $21.0 \pm 0.15^{\mathrm{Bb}}$ & $16.0 \pm 0.25^{\mathrm{Cc}}$ \\
$100 / 0$ & $5.9 \pm 0.14^{\mathrm{Gb}}$ & $18.1 \pm 0.14^{\mathrm{Ca}}$ & ${ }^{*} 0.0 \pm 0^{\mathrm{Ic}}$ \\
\hline
\end{tabular}

Table 2 shows the percent protein calculated from the total nitrogen under different mixing ratios of alfalfa and barley irrigated with fresh water, rainwater, and treated wastewater.

Results showed that the \% protein of the different ratios of alfalfa and barley irrigated with fresh water is significantly different between the different ratios indicated by capital letters (A, B, C, D, E, F, G, and H), except between the ratios $50 / 50$ and $90 / 10$ indicated by capital letter $\mathrm{D}$ and between the ratios $60 / 40$ and 100/0 indicated by the capital letter F, which are not significantly different. The highest protein $\%$ was found to be 31.9 and the lowest one was found to be 1.9 for the ratios 10/90 and 30/70 of alfalfa/barley, respectively. The same statistical analyses were conducted for the different ratios of alfalfa/barley irrigated with rainwater and treated wastewater. For those irrigated with rainwater, significant differences in the protein $\%$ was obtained between the different ratios indicated by the capital letters A, B, C, D, E, F, $\mathrm{G}$, and $\mathrm{H}$. The range of protein \% was found to be 4.6-19.0. For those irrigated with treated wastewater, significant differences were also obtained with the range of 4.9-28.4 for $\%$ protein.

Comparing the protein \% for alfalfa/barley different ratios irrigated with fresh water, rainwater, and grey water: the highest protein $\%$ was found to be for that irrigated with fresh water ( 31.9 for 10/90 alfalfa/barley ratio) followed by that irrigated with treated grey water (28.4 for 20/80 alfalfa/ barley ratio) and then for the 30/70 ratio irrigated with treated wastewater $(22.5 \%)$, and then for the $100 / 0$ ratio of alfalfa/barley irrigated with rainwater (19.0).

Statistical analysis was also conducted to study the effect of irrigation (fresh water, rainwater, and treated wastewater) on the $\%$ protein indicated by the small letters ( $a, b$, and $c$ ). The results showed significant differences in the protein $\%$ of alfalfa/barley ratios when the irrigation varies. As can be seen from Table 2, the protein \% was found to be higher for the following mixing ratios when irrigated with wastewater: 0/100, 20/80, 30/70, 50/50, 60/40, 70/30, and 90/10.

Table 3 shows the percent protein calculated from the total nitrogen under different mixing ratios of vetch and barley irrigated with fresh water, rainwater, and treated wastewater.
Results showed that the \% protein of the different ratios of vetch/barley irrigated with fresh water is significantly different between the different ratios indicated by capital letters (A, B, C, D, E, F, G, H, and I), except between the ratios $10 / 90$ and $20 / 80$ indicated by capital letter $D$ and between the ratios $60 / 40$ and $100 / 0$ indicated by the capital letter G, which are not significantly different. The highest protein \% was found to be 35.0 and the lowest one was found to be 1.6 for the ratio $90 / 10$ and $70 / 30$ of vetch/barley, respectively. The same statistical analyses were conducted for the different ratios of vetch/barley irrigated with rainwater and treated wastewater. For those irrigated with rainwater, significant differences in the protein \% was obtained between the different ratios indicated by the capital letters A, B, C, D, E, F, G, and $\mathrm{H}$. The range of protein $\%$ was found to be 10.1-23.5. For those irrigated with treated wastewater, significant differences were also obtained with the range of $0.0-22.4$ for $\%$ protein.

Comparing the protein \% for different vetch/barley ratios irrigated with fresh water, rainwater, and wastewater, the highest protein $\%$ was found to be for that irrigated with fresh water (35.0 and 24.3 for $90 / 10$ and $80 / 20$ vetch/barley ratio, respectively) followed by that irrigated with rainwater ( 23.5 for $30 / 70$ vetch/barley ratio) and then for the 10/90 ratio irrigated with treated wastewater (22.4\%).

Statistical analysis was also conducted to study the effect of irrigation (fresh water, rainwater, and treated wastewater) on the $\%$ protein indicated by the small letters ( $a, b$, and $c)$. The results showed significant differences in the protein $\%$ of vetch/barley ratios when the irrigation varies. As can be seen from Table 3, the protein \% was found to be higher for the following mixing ratios when irrigated with wastewater: 10/ $90,20 / 80,40 / 60$, and 50/50. While it was found highest for the mixing ratios $0 / 100,30 / 70,50 / 50,60 / 40,70 / 30$, and $100 /$ 0 when irrigated with rainwater; on the other hand, it was found highest for the mixing ratios $80 / 20$ and $90 / 10$ when irrigated with fresh water.

The fodder barley/alfalfa and barley/vetch on fresh water, treated grey water, and rainwater have resulted in some interesting positive crop yields that might have some economic benefits. This system of intercropping demonstrated that the fodder barley/alfalfa and barley/vetch arrangement on treated water gave comparable-if not better-outcome and benefits to those on fresh water and rainwater. However, the protein data system fluctuated in the yields, and no obvious trend was deduced as to which is the best ratio would be adopted. This could be attributed to various factors such as temperature and nature of each plant's morphology. Other factors that may influence forage quality are maturity (harvest date), harvest and storage, soil fertility, and variety (cultivar).

Plant morphology for both cereals and legumes has three main plant parts: leaf, stem, and grain. As a structural component of the plant, stems typically contain more fiber for supports. Leaves, on the other hand, provide a means for capture and utilization of energy from sunlight and trend to be lower in fiber content than stems, and thus stems usually are lower in digestibility than leaves, and stem digestibility declines more rapidly with increased plant maturity than 
that of leaves. Differences between leaf and stem digestibility are normally greater in forage legumes than cereals. Given the large difference between the digestible fiber content of stems and leaves, the proportion of leaf to stem in the given forage plant relates directly to its forage quality. Also, the grain mainly comprises digestible components such as starch and protein. Consequently, the grain-to-stover ratio is considered an indicator for variety selection when highquality forage is required.

The protein yield data can serve as an indicator of how intercropping on treated wastewater effectively gave better results than that on either fresh or rainwater. This partially (and probably) is due to the fact that treated wastewater is rich with nutrients $(\mathrm{N}, \mathrm{P}$, and $\mathrm{K}$ ) that are necessary for plant growth and yield. For example, at the 10/90 mixing ratio of vetch/barley, the protein content was $22 \%$ when cultivated on treated wastewater, $19 \%$ when cultivated on rainwater, and only $5 \%$ when cultivated on fresh water. Moreover, the alfalfa/barley $20 / 80$ intercropping ratio gave $28 \%$ of crude protein when irrigated with treated wastewater, $11 \%$ crude protein when grown using rainwater, and 6\% when using rainwater. The intercropping irrigated with fresh water was characterized by low-protein crop yields and net benefits.

\section{Conclusions}

In conclusion, the fodder barley/alfalfa and barley/vetch on treated grey water have resulted in robust comparable results in protein crop yields and net benefits, in comparison with the irrigation of intercropping system on fresh water or rainwater. It appears that the best result for protein percentages was (on average) obtained from the rain-fed experiment $(17.1 \%$ protein) followed by the freshwater experiment $(12.9 \%$ protein) and then by the treated wastewater experiment $(12.6 \%$ protein). Intercropping barley with common vetch improved the forage quality and increased the protein yield of barley without reducing dry matter yield. Overall, results of this study showed that cereallegume intercropping irrigated with treated wastewater can be used as a suitable management strategy for producing high-quality and high-quantity forage. The yield benefits depend on the correct implementation of the intercropping system, which is recommended for adoption by farmers but will therefore require some investment in workshop training and further research.

\section{Data Availability}

The data used to support the findings of this study are included within the article.

\section{Conflicts of Interest}

The authors declare no conflicts of interest.

\section{Acknowledgments}

The authors thank the FAO (Livestock-Based Livelihoodinstitutional Component (LBL-i)) for supporting this research through the EU. The authors also thank Dr. Khawla
Alnjoum, FAO, and the NARC research team and AAUP research team.

\section{References}

[1] F. Gou, M. K. van Ittersum, P. E. L. van der Putten, W. van der Werf, and P. Putten, "Yield and yield components of wheat and maize in wheat-maize intercropping in The Netherlands," European Journal of Agronomy, vol. 76, pp. 17-27, 2016.

[2] B. Mekonnon, "Selection of barley varieties for their yield potential at low rain fall area based on both quantitative and qualitative characters north west tigray, shire, Ethiopia," International Journal of Plant Breeding and Genetics, vol. 8, pp. 205-213, 2014.

[3] G. Stanhill and C. Rapaport, "Temporal and spatial variation in the volume of rain falling annually in israel," Climate Research, vol. 37, pp. 211-221, 1988.

[4] I. Torres Sizenando, J. Pierre, J. Fernandes, P. Ivan, and L. F. Lima, "Agronomic efficiency of Bradyrhizobium in peanut under different environments in Brazilian Northeast," African Journal of Agriculture Research, vol. 11, pp. 34823487, 2016.

[5] V. Loïc, B. Laurent, J. Etienne-Pascal, and J. Eric, "Yield gap analysis extended to marketable grain reveals the profitability of organic lentil-spring wheat intercrops," Agronomy for Sustainable Development, vol. 38, no. 4, p. 38, 2018.

[6] L. Bedoussac, E.-P. Journet, E.-P. Journet et al., "Grain legume-cereal intercropping systems," Achieving sustainable cultivation of grain legumes, vol. 1, pp. 243-256, 2018.

[7] A. M. Komarek, J. Haile, S. Msangi, C. Azzarri, S. Msangi, and C. Azzarri, "Trade-offs and synergies between yield, labor, profit, and risk in Malawian maize-based cropping systems," Agronomy for Sustainable Development, vol. 38, no. 3, p. 38, 2018.

[8] H. Gitari, Potato-Legume Intercrop Effects on Water and Nutrients Use Efficiency, Crop Productivity and Soil Fertility in a Humic Nitisol, Thesis for: PhD, Kenya, 2018.

[9] L. Ma, Y. Li, P. Wu, X. Zhao, X. Chen, and X. Gao, "Effects of varied water regimes on root development and its relations with soil water under wheat/maize intercropping system," Plant and Soil, vol. 439, no. 1-2, pp. 113-130, 2018.

[10] P. Dodiya, A. Gadhiya, and G. D. Patel, "A review: effect of inter cropping in horticultural crops," International Journal of Current Microbiology and Applied Sciences, vol. 7, pp. 15121520, 2018.

[11] W. Willey and R. Evaluation, "Presentation of Intercropping Advantages," Experimental Agriculture, vol. 21, pp. 119-133, 1985.

[12] N. Jiao, Y.-H. Li, L. Liu et al., "Effects of root barrier on photosynthetic characteristics and intercropping advantage of maize||peanut intercropping," National Nature Science Foundation of China, vol. 52, pp. 886-894, 2016.

[13] B. J. R. Alves, L. Zotarelli, W. A. R. Lara-Cabezas et al., "Benefit of legume-fixed $\mathrm{N}$ in crop rotations under zerotillage," Nitrogen Fixation: From Molecules to Crop Productivity, vol. 38, pp. 533-534, 2002.

[14] P. M. Chalk and P. Dynamics, "Dynamics of biologically fixed $\mathrm{N}$ in legume-cereal rotations: a review," Australian Journal of Agricultural Research, vol. 49, no. 3, Article ID 303, 1998.

[15] R. Dudal, "Land resources for the world's food production," Land Resources for the World's Food Production. Der Weltkohlenhandel, vol. 7, pp. 7-26, 1984. 
[16] J. Guyader, V. Baron, and K. Beauchemin, "Corn forage yield and quality for silage in short growing season areas of the canadian prairies," Agronomy, vol. 8, no. 9, p. 164, 2018.

[17] E. DePeters and J. \& L. Medrano, "Bath, Donald \& P. Harper, Donald. Cereal forage for dairy cattle," California Agriculture, vol. 44, pp. 21-23, 1990.

[18] W. M. Azo, G. P. F. Lane, W. Davies, and N. Cannon, "Predicting yields and protein content of lupin/cereal forage crops in organic farming," in Proceedings of the Precision Agriculture 2009 - Papers Presented at the 7th European Conference on Precision Agriculture, ECPA, Cirencester, Gloucestershire GL7 6JS UK, pp. 667-674, 2009.

[19] D. Sagar and H. Dhall, "Legumes: potential source of entomotoxic proteins- A review," Legume Research An International Journal, vol. 41, no. 5, 2018.

[20] D. Prakash, Abhishek Niranjan, S.K. Te, A. Niranjan, S. Tewari, and P. Pushpangadan, "Underutilised legumes: potential sources for low-cost protein," International Journal of Food Sciences and Nutrition, vol. 52, no. 4, pp. 337-341, 2001.

[21] G. Jahreis, M. Brese, M. Leiterer, U. Schäfer, and V. Böhm, "Legume flours: nutritionally important sources of protein and dietary fiber," Ernahrungs - Umschau, vol. 63, pp. 36-42, 2016.

[22] L. Cavallarin, E. Tabacco, and G. Borreani, "Forage and grain legume silages as a valuable source of proteins for dairy cows," Italian Journal of Animal Science, vol. 6, pp. 282-284, 2007.

[23] H. Al-Hamaiedeh and M. Bino, "Effect of treated grey water reuse in irrigation on soil and plants," Desalination, vol. 256, no. 1-3, pp. 115-119, 2010.

[24] J. Wen, J. Yang, and T. Wang, "Path planning for autonomous underwater vehicles under the influence of ocean currents based on a fusion heuristic algorithm," IEEE Transactions on Vehicular Technology, vol. 70, no. 9, pp. 8529-8544, 2021. 